\title{
Italian Consensus Statement on Management of HIV-Infected Individuals with Advanced Disease Naïve to Antiretroviral Therapy
}

\author{
A. Antinori, A. Ammassari, C. Torti, P. Marconi, M. Andreoni, G. Angarano, S. Bonora, \\ A. Castagna, R. Cauda, M. Clerici, A. d'Arminio Monforte, A. De Luca, G. Di Perri, M. Galli, \\ E. Girardi, A. Gori, A. Lazzarin, S. Lo Caputo, F. Mazzotta, F. Montella, C. Mussini, \\ C. F. Perno, M. Puoti, G. Rizzardini, S. Rusconi, V. Vullo, G. Carosi
}

\begin{abstract}
Background: Individuals with advanced HIV infection naïve to antiretroviral therapy represent a special population of patients frequently encountered in clinical practice. They are at high risk of disease progression and death, and their viroimmunologic response following the initiation of highly active antiretroviral therapy may be more incomplete or slower than that of other patients. Infection management in such patients can also be complicated by underlying conditions, comorbidities, and the need for concomitant medications. Aim: To provide practical guidelines to those clinicians providing care to HIV-infected patients in terms of diagnostic assessment, monitoring, and treatment.

Conclusions: The principals of antiretroviral treatment in asymptomatic naïve patients with advanced HIV infection are the same as those applicable to the general population with asymptomatic HIV infection. Naïve patients with advanced HIV infection and a history of AIDS-defining illnesses urgently need antiretroviral treatment, with the choice of antiretroviral regimen and timetable based on such factors as concomitant treatment and prophylaxis, drug interactions, and potential concomitant drug toxicity. Finally, an adequate counseling program - both before and after HIV-testing - that includes aspects other than treatment adherence monitoring is a crucial step in disease management.
\end{abstract}

Infection 2009; 37: 270-282

DOI 10.1007/s15010-008-8134-8

\section{Introduction}

Despite a general awareness of the fact that early HIV screening is advisable, a considerable proportion of individuals in developed countries receive a new diagnosis of HIV infection at an advanced disease stage, when AIDSrelated diseases or symptoms are already present [1-3]. High plasma HIV-RNA levels and low CD4+ cell counts, typically found in advanced stages of HIV disease, are both associated with an increased risk of mortality, even after the initiation of combination antiretroviral therapy (cART) [4, 5]. In addition, even after cART has been initiated, early viro-immunologic response may be incomplete or slower in patients with more advanced HIV infection at baseline [6,7], and it is also strongly associated with subsequent disease progression [8].

\footnotetext{
A. Antinori (corresponding author), A. Ammassari, P. Marconi, E. Girardi

Istituto Nazionale Malattie Infettive "Lazzaro Spallanzani" IRCCS, via Portuense 292, 00149, Rome, Italy; Phone: (+39/06) 5517-0348, Fax: -0477, e-mail: antinori@inmi.it

C. Torti, M. Puoti, G. Carosi

Clinica Malattie Infettive e Tropicali, Università degli Studi, Brescia, Italy M. Andreoni, C.F. Perno

Università di Roma "Tor Vergata", Rome, Italy

G. Angarano

Università degli Studi, Foggia, Italy

S. Bonora, G. Di Perri

Ospedale Amedeo di Savoia, Università degli Studi, Turin, Italy

A. Castagna, A. Lazzarin

Università "Vita e Salute", San Raffaele, Milan, Italy

R. Cauda, A. De Luca

Università Cattolica del Sacro Cuoro, Rome, Italy

M. Clerici

Università degli Studi, Milan, Italy

A. d'Arminio Monforte

A.O. San Paolo, Università degli Studi, Milan, Italy

M. Galli, S. Rusconi

Ospedale L. Sacco, Università degli Studi, Milan, Italy

A. Gori

Ospedale S. Gerardo, Università Milano-Bicocca, Monza, Italy

S. Lo Caputo, F. Mazzotta

Ospedale S.M. Annunziata, Florence, Italy

F. Montella

Ospedale S. Giovanni Addolorata, Rome, Italy

C. Mussini

Policlinico Universitario, Università degli Studi, Modena, Italy

G. Rizzardini

Ospedale Luigi Sacco, Milan, Italy

v. Vullo

Università “La Sapienza”, Rome, Italy
}

Received: April 3, 2008 - Revision accepted: September 10, 2008 Published online: May 28, 2009 
Proper clinical management of antiretroviral therapy in patients with advanced HIV infection by appropriate, timely, and efficacious prescriptions is therefore crucial to an improved prognosis $[9,10]$. When treating special patient populations, clinicians also need to take into account co-morbidities, concomitant treatments, and medical problems specific to that particular patient population.

This document is a consensus statement resulting from a consensus conference of experts and clinicians active in the field of HIV infection and treatment. This aim of this conference was to outline our current understanding of advanced HIV infection clinical management and develop recommendations for clinicians.

\section{Methods}

The recommendations presented here are the result of a consensus workshop which took place in Rome, Italy, on December 2006. The 2-day workshop started with two introductory plenary lectures held by international experts on the issues covered by the consensus conference. Thereafter, a draft of the statements and a grading system classifying the strength of the recommendations and the quality of evidence were presented by 27 Italian experts in the field, who had previously searched, reviewed, and synthesized the literature specifically pertaining to the topics. The strength of the recommendations was graded as strong (A), moderate (B), and optional (C); the quality of the evidence was classified as I, indicating properly randomized controlled trials with clinical and/or laboratory results; II, indicating other published studies with clinical and/or laboratory results; III, indicating expert opinion. Four main topics were covered:

1. diagnostic assessments and monitoring of naïve patients with advanced HIV infection;

2. principles of antiretroviral treatment in naïve patients with asymptomatic advanced HIV infection;

3. principles of antiretroviral treatment and monitoring of naïve patients with advanced HIV infection and opportunistic disorders, and at high risk of death (AIDS presenter);

4. principles of antiretroviral treatment and monitoring of naïve patients with advanced HIV infection and special conditions or co-morbidities.

Four working groups, each comprising 10-15 Italian HIVtreating physicians, reviewed and modified these preliminary statements according to the current literature and their personal clinical experiences. The revised statements were presented in a plenary session and voted by all consensus participants: they were then either accepted or re-discussed and re-voted according to the degree of agreement reached.

\section{Diagnostic Assessments and Monitoring in Naïve Patients with Advanced HIV Infection Introduction}

The early and correct identification of patients with an advanced naïve HIV infection is addressed here. A correct definition of the laboratory tests recommended for these patients at baseline and follow-up visits is essential to disease staging, monitoring of eventual therapy-related toxicities, and risk assessment of opportunistic infections.
Initial clinical management is crucial for these patients, since it will represent the basis for a trusting relationship with the health care staff.

\section{Definition of Advanced Naïve HIV-Infection}

Patients with advanced HIV infection naïve to antiretrovirals are individuals presenting with one or both of the following two conditions at HIV diagnosis: (1) stage C according to 1993 Revised Classification System for HIV infection [11] (A-II); (b) CD4+ T cell count $\leq 200 / \mathrm{mm}^{3}$ on two consecutive determinations (B-II). However, this definition should be viewed in a larger context. Older age ( $\geq 60$ years) or coexisting illnesses at diagnosis of HIV infection could also be included in the definition of advanced naïve patients, if the negative effects of these conditions on quality of life, disease progression, immunologic response to treatment, and cART-related toxicities are taken into account [12] (B-II).

As a result of the clinical complexity of naïve patients with advanced HIV infection [2], clinicians should make every possible effort to facilitate early detection of HIV infection (A-II).

\section{Patient Support}

Special care and psychological support of patients with advanced naive HIV infection during the initial clinical assessment are necessary. Patients may have to receive many different pieces of information at the same time: positive test for HIV antibody, urgency of promptly starting cART and, perhaps, the need for treatment of opportunistic infections. Therefore, adequate counseling both before and after HIV-testing is crucial (A-II). Depending on the patients' desire to conceal or disclose their HIV status to trusted family members, partners, and friends, the latter may become involved in the patient support counseling.

\section{HIV-Surrogate Markers and Resistance Testing}

On a routine basis, blood examinations, such as complete blood cell count and chemistry profile (A-III), lymphocyte cell count (absolute and percentage value of both CD4+ and CD8+ T cells) (A-I) [13], and plasma HIVRNA levels (viral load) [4] (A-I), need to be assessed at the first and all follow-up visits (Table 1). Two distinct baseline measurements of CD4+ T cell count should be obtained - at least 1 week apart if possible - because of a possible variation in results (C-III). Although the absolute $\mathrm{CD} 4+\mathrm{T}$ cell count is the most commonly used parameter in clinical practice, the percentage of $\mathrm{CD} 4+\mathrm{T}$ cells is somewhat less variable than the absolute count, and the latter may provide additional information when immune function is assessed (C-III). Other lymphocytic subpopulations, such as CD8/CD38+ T cells, are measurable and may be considered a marker of both disease progression and response to treatment regardless of other viroimmunologic parameters (C-III). During opportunistic 


\begin{tabular}{|c|c|}
\hline \multicolumn{2}{|c|}{$\begin{array}{l}\text { Table } 1 \\
\text { Laboratory examinations that should be performed in patients } \\
\text { with advanced naïve HIV infection at baseline and/or on a } \\
\text { routine basis. }\end{array}$} \\
\hline & $\begin{array}{l}\text { Complete blood count } \\
\text { Lymphocyte subpopulations }\end{array}$ \\
\hline Serum chemistry & $\begin{array}{l}\text { Fasting blood glucose } \\
\text { Electrolytes }(\mathrm{Na} / \mathrm{K} / \mathrm{Ca} / \mathrm{P}) \text {, creatinine } \\
\text { Transaminase levels, bilirubin, } \gamma \mathrm{GT}, \mathrm{LDH}, \mathrm{CK} \\
\text { Albumin } \\
\text { Alkaline phosphatase, amylase } \\
\text { Fasting triglycerides, cholesterol } \\
\text { (total, HDL, LDL) } \\
\text { Urinalysis } \\
\text { C-reactive protein }\end{array}$ \\
\hline Virological tests & $\begin{array}{l}\text { Plasma HIV RNA } \\
\text { Viral subtype } \\
\text { Genotypic resistance test }\end{array}$ \\
\hline Serological tests & $\begin{array}{l}\text { RPR or VDRL (confirmatory test FTA-ABS) } \\
\text { CMV Ag and IgG/M, EBV IgG/M } \\
\text { Toxoplasma gondii IgG } \\
\text { Cryptococcal antigen } \\
\text { HBsAg, HBsAb, HBcAb, HCV IgG, HAV IgG }\end{array}$ \\
\hline $\begin{array}{l}\text { Cytology } \\
\text { Microbiology }\end{array}$ & $\begin{array}{l}\text { Papanicolaou smear test of the cervix } \\
\text { Search for pathogens responsible of other } \\
\text { sexually transmitted diseases } \\
\text { (such as Chlamydia trachomatis, Neisseria } \\
\text { gonorrhoeae, HPV-PCR and genotyping) }\end{array}$ \\
\hline \multicolumn{2}{|c|}{$\begin{array}{l}\gamma \mathrm{GT}: \gamma \text {-Glutamyl transferase; LDH: lactate dehydrogenase; CK: cre- } \\
\text { atine kinase; HDL: high-density lipoprotein; LDL: low-density } \\
\text { lipoprotein; RPR: rapid plasma reagin; VDRL: venereal disease re- } \\
\text { search laboratory; FTA-ABS: fluorescent treponemal antibody } \\
\text { absorption; CMV: cytomegalovirus; EBV: Epstein-Barr virus; HBsAg: } \\
\text { surface antigen of the Hepatitis B virus; HbsAb: hepatitis B surface } \\
\text { antibody; HBcAb: hepatitis B core antibody; HCV: hepatitis C virus; } \\
\text { HAV: hepatitis A virus; HPV: human papillomavirus }\end{array}$} \\
\hline
\end{tabular}

infections (e.g., tuberculosis, cytomegalovirus [CMV]), virologic and immunologic parameters may be less helpful than usual in evaluating the risk of disease progression in single patients since they may be wrongly reduced or elevated [14]. Viro-immunologic parameters should be repeated in these cases (A-II).

Genotypic resistance testing should be carried out [15] (A-II) and viral subtype determination performed (B-III) in all naïve patients with advanced HIV infection. Regardless of the imminent necessity to start cART, the genotypic assay is helpful in guiding the selection of treatment strategies [15]. Nevertheless, there is no reason for delaying the initiation of cART while awaiting the results of the test in patients at a high risk of disease progression: in these cases, treatment should be started promptly using drugs with a high genetic barrier and eventually modified thereafter on the basis of the result of the genotypic test (A-III). In terms of research applied to genotypic resistance testing, it could be interesting to consider innovative methodologies to identify specific mutations as minority quasi-species (e.g., single genome assay or allele-specific PCR for detecting the K103N mutation) [16] (B-III).

In the future, the determination of HIV-1 cell receptor (CCR5, CXCR4, or mixed/dual CXCR4/CCR5) tropism may be appropriate to design innovative strategies by using entry inhibitors in early phases of treatment. Nevertheless, this test currently does not seem to provide additional information since no significant differences in mean CD4+ $\mathrm{T}$ cell count increases in patients with either CXCR4- or CCR5-tropic HIV-1 have been observed [17]. Although an investigation of other virologic markers, such as proviral DNA, appears to be interesting in terms of gaining a better understanding of the pathogenetic mechanism of HIV and being able to better evaluate the response to cART, it should not yet be considered a part of standard monitoring procedures (B-III).

\section{Other Laboratory Assessments}

The hypersensitivity reaction to abacavir is strongly associated with the presence of the HLA-B*5701 allele and, therefore, pharmacogenetic testing should be used to prevent the specific toxic effect of the drug [10, 18] (A-I).

Adequate screening of the hepatitis viruses (HV) determining chronic disease (HCV, HBV, HDV) needs to be carried out (Table 1) (A-III). False negative results of some diagnostic tests may occur in patients with advanced HIV infection, particularly in patients with strong immunosuppression; such results generally concern antibodies against hepatitis B surface antigen, HCV, and Toxoplasma gondii [19]. Based on this fact, despite HCVantibody negativity, determination of plasma HCV-RNA should be performed in all patients with advanced HIV infection having unexplained high levels of serum transaminases (B-II).

The tuberculin skin test is yet another test whose result may be affected by the loss of cellular immune function. A chest radiograph should be performed in the presence of respiratory symptoms - even if no skin induration $\geq 5 \mathrm{~mm}$ is evident - and three sputum samples should be collected to investigate the presence of acid-fast bacilli as well as to culture for mycobacteria (A-II). A low sensitivity to the skin tuberculin test will be overcome, in part, by the introduction of two blood tests (T-SPOT.TB and Quantiferon-TB Gold), which are based on the detection of IFN-gamma released by $\mathrm{T}$ lymphocytes in response to Mycobacterium tuberculosis-specific antigens. Clinical studies examining these new tests in the HIV patient population are in progress [20].

\section{Additional Tests}

A baseline chest radiograph should be reserved for all patients with advanced HIV infection and naïve to antiretroviral therapy, particularly if they have a prior history of pulmonary disease or active pulmonary problems (A-III). An electrocardiogram should be considered as a 
component of the initial assessment if clinically indicated (B-III). Finally, routine screening for health-maintenance issues, particularly those defined by age-appropriate standard-of-care, should be included (e.g., prostate-specific antigen determination, mammography, test for occult blood in stool) (B-III).

\section{Opportunistic Diseases and Concomitant Conditions}

Patients with advanced naïve HIV infection carry a substantially increased risk of the following concomitant conditions that may complicate clinical management by worsening disease prognosis and response to treatment $[3,12]$ :

- presence of opportunistic infections [1];

- co-morbidities, such as chronic liver diseases, malignancies, etc. [12];

- older age $[13,21]$;

- immune reconstitution inflammatory syndrome (IRIS) $[22,23]$;

- need for concomitant medications (e.g., concomitant prevention/treatment of opportunistic infections);

- psychological distress.

In particular, the presence of concomitant opportunistic diseases should be evaluated by assessing the following (A-II):

- medical history and complete physical examination;

- routine blood tests (hematology and chemistry);

- instrumental examinations based on specific signs and symptoms (chest X-ray, brain CT scan, endoscopy, etc.);

- biopsy samples (e.g., lymph node, liver);

- serological and virological tests as well as cultures (where appropriate) to detect specific opportunistic pathogens (CMV, Pneumocystis jiroveci, mycobacteria, T. gondii, Cryptococcus neoformans, etc.).

A funduscopic examination in patients having a CD4+ T cell count $<100 / \mathrm{mmc}$ may be appropriate (B-II).

Advanced naïve patients should receive an intensive follow-up program, especially during the initial treatment phase (B-II) because the risk of opportunistic infections during the first 12 months is reduced, but not eliminated by cART [24-27].

\section{Monitoring Antiretroviral Therapy Efficacy and cART-Related Toxicities}

One month after initiating cART, treatment efficacy should be evaluated by determining lymphocyte subpopulations (absolute and percentage value of CD4+ T cells) (A-I), and plasma HIV-RNA levels (A-I). Once an antiretroviral treatment has begun, patients should be carefully monitored by means of blood tests in order to guard against the risk of different cART-related toxicities (A-II). It may also be advisable to store a blood sample for future diagnostic procedures (C-III).
Advanced naïve HIV patients are generally older than early HIV presenters: both advanced age and HIV infection are associated with an increase in cardiovascular risks. Moreover, prolonged exposure to cART, in particular to regimens containing protease inhibitors, induces metabolic alterations that represent an additional risk factor for cardiovascular events. Hence, the assessment, monitoring, and correction of likely cardiovascular risk factors should be implemented [28] (A-II).

Immune Reconstitution Inflammatory Syndrome Immune reconstitution inflammatory syndrome is a clinical condition observed in some AIDS patients, in which the immune system begins to recover and to respond to a previously acquired opportunistic infection with an overwhelming inflammatory response that paradoxically worsens the symptoms of infection. Since the onset of IRIS highly complicates the management of naïve patients with advanced HIV infection, strategies to prevent IRIS by identifying patients with possible ongoing opportunistic infections during the initial phase of cART treatment should be developed [22, 23] (B-II). As IRIS has been associated with the reactivation of the organism's response to almost all opportunistic infections, a well-established diagnostic procedure should be elaborated (B-II).

\section{Principles of Antiretroviral Treatment in Naïve Patients with Asymptomatic Advanced HIV Infection \\ Introduction}

The principal objectives of cART are to reduce HIV-related morbidity and mortality, to restore immune system, to suppress viral replication as long as possible, and to improve quality of life. The decision of when to initiate antiretroviral treatment in asymptomatic patients should be based on their prognosis, as determined by the CD4+ $\mathrm{T}$ cell count and plasma HIV-RNA values at the baseline visit, possible drugrelated toxicity, and adherence issues $[4,8,21]$.

In general, the principles of antiretroviral treatment in this sub-group of patients are the same as those applicable to the general population with asymptomatic HIV infection. Therefore, only special concepts of advanced naive patients with respect to the general HIV population will be highlighted in the present guidelines.

\section{General Recommendations}

Based on the results of randomized trials and observational cohorts which focused on the high risk of disease progression, the initiation of antiretroviral treatment is strongly recommended in all patients with a CD4+ T cell count $<200 / \mathrm{mm}^{3}$ [4, 8, 21, 29] (A-I). In these patients antiretroviral treatment should be started as soon as possible (A-II) and be coupled with both a previous comprehensive clinical as well as pharmacological evaluation and an accurate counseling program on adherence to treatment [30] (A-III). 
Taking into consideration both the risk of clinical progression and the relevance of achieving a prompt suppression of viral replication, the panel strongly recommends that initial antiretroviral regimen be selected on the basis of HIV genotypic test results [15] (A-II).

\section{Choice of Antiretroviral Treatment}

Randomized prospective trials comparing treatment strategies in exclusively advanced patients are few and therefore desirable. Preliminary data on the short-medium efficacy and safety of first-line antiretroviral regimens are derived from observational studies as well as randomized trials, including asymptomatic patients without CD4+ T cells count restriction.

A virologic, but not immunologic, superiority has been documented for non-nucleoside reverse transcriptase inhibitors (NNRTI)-based regimens when these are compared to mostly unboosted protease inhibitor (PI)based cART in randomized trials and retrospective cohort studies [31, 32]. One randomized comparative trial performed in a naïve patient population containing a relevant proportion (about $40 \%$ ) of patients with advanced HIV infection showed that lopinavir/ritonavir (LPV/r)-containing regimens were associated with a better CD4+ T cell count increase as well as with a reduced risk of resistance mutation development at treatment failure, while efavirenz-containing regimens showed more likely virologic success [33]. Data from prospective observational studies did not show substantial differences between NNRTI-based and PI/r-based regimens with reference to virologic efficacy and/or clinical outcome [34, 35]. However, in prospective non-randomized studies and in non-comparative randomized trials, LPV/r-containing regimens had a persistent immunologic efficacy, a better immunologic recovery, and no primary resistance-associ- ated mutation development in patients with suppressed viral load [36, 37].

Based on the finding that regimens including other boosted-PIs showed non-inferior results, as evidenced in comparative trials at short-term follow-up, these can be considered for regimen building [38-40] (B-I).

While numerous data are available on the potency of regimens containing efavirenz [32,34], empirical evidence for using regimens containing nevirapine in this population is limited (B-I). Even if specific studies on a direct comparison are lacking, regimens containing non-thymidine nucleoside analogues seem to be more desirable since they are associated with a better CD4+ cells recovery (B-I).

Antiretroviral regimens containing four drugs, based either on a combination of drugs belonging to all three antiretroviral drug classes (NRTI-NNRTI-PI) or on the association of three nucleoside analogues and an NNRTI drug, did not show an advantage relative to the standard of care [41]. Based on available data, antiretroviral treatment with $\mathrm{PI} / \mathrm{r}$ monotherapy is not advisable in this patient population [42] (A-I). To date, data are inadequate for supporting the introduction of fusion inhibitors [43] or immunomodulators (e.g. IL-2) in the first antiretroviral regimens (A-II).

\section{Concomitant Treatments}

The risk of opportunistic infections in patients with advanced naïve HIV infection persists throughout the entire phase of immunosuppression and even lasts several months following the start of cART [25, 26]. For this reason, patients with low CD4+ T cell counts should receive primary prophylaxis for opportunistic infections (A-II). The drug regimens used for specific opportunistic infections and the CD4+ T cell count below which prophylaxis is indicated are summarized in table 2.

Table 2

Type of regimen for primary prophylaxis of opportunistic infections and timing.

\begin{tabular}{|c|c|c|c|}
\hline & PCP & Toxoplasmic encephalitis & MAC infection \\
\hline $\begin{array}{l}\text { CD4+ T cell count below which } \\
\text { prophylaxis should be started }\end{array}$ & $<200$ cells $/ \mathrm{mm}^{3}$ & $<100$ cells $/ \mathrm{mm}^{3}$ & $<50$ cells $/ \mathrm{mm}^{3}$ \\
\hline Preferred regimen & $\begin{array}{l}\text { Trimethoprim-sulfamethoxazole } \\
\text { double-strength (DS) tablet } \\
1 \text { tablet by mouth daily (A-I) } \\
1 \text { tablet by mouth three times } \\
\text { weekly (B-II) }\end{array}$ & $\begin{array}{l}\text { Trimethoprim-sulfamethoxazole } \\
\text { DS } 1 \text { tablet by mouth daily (A-I) }\end{array}$ & $\begin{array}{l}\text { Clarithromycin } 500 \mathrm{mg} \text { by mouth } \\
\text { twice daily }(A-I) \\
\text { Azithromycin } 1,200 \mathrm{mg} \text { by mouth } \\
\text { weekly }(A-I)\end{array}$ \\
\hline Alternative regimen & $\begin{array}{l}\text { Aerosolized pentamidine } 300 \mathrm{mg} \\
\text { monthly via aerosol } \\
\text { Dapsone } 100 \mathrm{mg} \text { by mouth daily } \\
\text { Atovaquone } 1,500 \mathrm{mg} \text { by mouth } \\
\text { daily }\end{array}$ & $\begin{array}{l}\text { Dapsone } 50 \text { mg by mouth daily } \\
\text { plus pyrimethamine } 50 \mathrm{mg} \text { by } \\
\text { mouth weekly plus leucovorin } \\
25 \mathrm{mg} \text { by mouth weekly } \\
\text { Atovaquone } 1,500 \mathrm{mg} \text { by mouth } \\
\text { daily }\end{array}$ & Rifabutin $300 \mathrm{mg}$ by mouth daily \\
\hline $\begin{array}{l}\text { CD4+ T cell count above which } \\
\text { prophylaxis should be } \\
\text { discontinued }\end{array}$ & $>200$ cells $/ \mathrm{mm}^{3}$ for $\geq 3$ months & & $>100$ cells $/ \mathrm{mm}^{3}$ for $\geq 3$ months \\
\hline
\end{tabular}


Since there are no documented interactions between drugs used for primary prophylaxis of either $P$. jiroveci pneumonia (PCP) or toxoplasmic encephalitis (trimetho$\mathrm{prim} / \mathrm{sulphamethoxazole,} \mathrm{dapsone,} \mathrm{pentamidine)} \mathrm{and}$ currently available antiretrovirals, these can be used without concern (A-III).

PIs and NNRTIs are metabolized in the liver by the cytochrome P450 system, particularly by CYP3A4, so that drug-drug interaction should be checked in the presence of concomitant medications (A-III). Since rifamycins in general (rifabutin to a lesser extent) are CYP3A4 inducers, they should be used with caution when administered in association with other drugs inducing or inhibiting the same cytochrome enzyme (A-III). In fact, they can significantly reduce plasma concentrations of most PIs and NNRTIs.

Since interactions between macrolides and antiretroviral drugs do not seem to be clinically significant, dosage modifications are not necessary (A-III).

\section{Adherence}

Adherence to antiretroviral treatment is crucial to obtain and maintain virological suppression, to avoid the occurrence of HIV resistance, and to prolong survival [44-46]. Patient-reported non-adherence is a valid tool for assessing suboptimal antiretroviral intake and correlates with major treatment outcomes [44, 45, 47]. Clinicians should be able to reassure the patient while emphasizing the importance of adherence and the risks associated with an incorrect intake of the prescribed treatments (A-II).

Interaction between patients and their health care providers should be close and constant in order that the latter be able to carefully evaluate treatment adherence and to promptly monitor the onset of side effects possibly related to cART or, eventually, to other concomitant treatments. Adequate counseling to reinforce adherence (A-I), provide psychological support, and treat potential psychiatric disorders and drug dependence (A-II) should be considered both before and during the administration of cART.

\section{Principles of Antiretroviral Treatment and Monitoring in Naïve Patients with Advanced HIV Infection, Opportunistic Disorders and High Risk of Death (Aids Presenter) Introduction}

Advanced naïve HIV-positive patients presenting with AIDS-defining illnesses or severe symptoms are at an extremely high risk of developing other opportunistic conditions or dying [3,23] and, therefore, urgently need antiretroviral treatment. This topic focuses on issues concerning the timing of cART initiation and the type of treatment regimen to be used.

\section{Timing of CART During Opportunistic Infections and Malignancies}

Antiretroviral treatment must be started in all HIV-infected patients with a diagnosis of AIDS and should be initiated, in the absence of contraindications, during the early stages of acute opportunistic infections $[10,48]$ (A-I). cART per se should be considered a therapeutic strategy for all opportunistic disorders for which an etiologic treatment against a specific agent is lacking: cryptosporidiosis, microsporidiosis, progressive multifocal leukoencephalopathy (PML), and localized cutaneous and mucosal Kaposi's sarcoma [3] (A-III). In these cases, cART should be started immediately, without awaiting the results of an HIV genotypic resistance test, preferably using high-genetic barrier drugs (A-III).

In the case of opportunistic infection for which an etiologic treatment is available ( $M$. avium-complex infection [MAC], PCP, cryptococcal meningitis, CMV infection, toxoplasmic encephalitis, esophageal candidiasis), cART may be deferred until stabilization of the clinical condition of the patient [3]. It is advisable, however, not to postpone the initiation of cART beyond 14 days from disease diagnosis, considering that immediate cART is associated with reduced death and AIDS progression and a shorter time to immune recovery [48-50] (C-I).

The following factors should be considered in the decision-making process on when to start cART:

- degree of immunosuppression;

- toxicity related to concomitant treatments;

- risk of IRIS;

- type of pathogen.

cART has been shown to improve outcome in ventilatorsupported patients hospitalized in the intensive care unit with severe PCP and to be an independent predictor of decreased mortality [51]. Thus, in patients with PCP, cART needs to be started before completion of the acute phase of anti- $P$. jiroveci treatment to avoid any possible complication of the clinical picture [52] (B-III). It is important that if there is either evidence of clinical worsening or a lack of response to etiologic treatment, cART should be started during the first 14 days (C-III).

Patients who receive the combination of cancer chemotherapy and cART may achieve better response rates than patients who receive antineoplastic therapy alone [53]. Some studies have reported that patients with Hodgkin's lymphoma (HL) or non-Hodgkin's lymphoma (NHL) who started cART at the same time as chemotherapy showed increased survival [54-56], reduced toxicity (especially bone marrow toxicity), and a decreased risk of developing opportunistic infections. Therefore, cART should be started before or at the same time as chemotherapy in patients diagnosed with HL, NHL, or Kaposis's sarcoma (A-I).

In patients with a diagnosis of non-AIDS-defining malignancies, antiretroviral treatment should be considered before or at the same time as chemotherapy treatment (C-III). While the benefit of cART in patients with 


\begin{tabular}{|c|c|c|c|}
\hline CD4+ $T$ cell count & Antitubercular treatment $^{\mathrm{a}}$ & CART & Recommendation $^{b}$ \\
\hline$<100$ cells $/ \mathrm{mm}^{3}$ & Rifampicin-based & Add after the first 15 days & C-III \\
\hline 100,200 cells $/ \mathrm{mm}^{3}$ & Rifampicin-based & $\begin{array}{l}\text { Add at completion of the initial phase of antitubercular } \\
\text { therapy or at least after the first month }\end{array}$ & C-III \\
\hline $200-350$ cells $/ \mathrm{mm}^{3}$ & Rifampicin-based & Evaluate cART indication every 2 months & C-III \\
\hline$>350$ cells $/ \mathrm{mm}^{3}$ & Rifampicin-based & $\begin{array}{l}\text { Evaluate cART indication after } 2 \text { months and } \\
\text { thereafter every } 3 \text { months }\end{array}$ & C-III \\
\hline
\end{tabular}

HL is supported by clinical evidence [57], there is no evidence of such an advantage in other malignancies. However, the unreliability of close immunologic monitoring, the clinical advantages observed in patients with HL and NHL, and the strong scientific rationale regarding anti-tumoral immunity support the starting of cART in this group of patients as well.

\section{Choice of Antiretroviral Drugs}

In terms of treatment efficacy, there is at yet no clear evidence of which is the best initial regimen (e.g. PI/r- or NNRTI-based cART) to be used to treat patients with ongoing HIV-related malignancies and opportunistic infections (C-III). Combinations of cART and treatments against opportunistic infections should be carefully selected in order not to overlap bone marrow, renal, or hepatic toxicities (A-II). In particular, NNRTIs should be avoided when therapy-induced hepatic toxicity is expected, zidovudine should not be used in case of possible mielotoxicity, tenofovir should not be considered in the presence of renal impairment, and didanosine/stavudine/zidovudine should not be included in the case of possible peripheral neurological toxicity (B-III).

It is likely that PIs should be preferred as part of an initial cART in the presence of a number of opportunistic infections, such as Candida spp, P. jiroveci, and Cryptococcus spp, since these drugs have shown a direct in vitro activity on these pathogens (C-III).

Optimal initial antiretroviral treatment options have not yet been established in patients with Kaposi's sarcoma. Both PI/r- and NNRTI-containing regimens have been shown to have comparable antiviral activity in reducing Kaposi's sarcoma-associated herpesvirus (KSHV) viremia. Nevertheless, based on in vitro experimental data, clinical evidence, and single case reports, several experts suggest the initial use of PI/r-containing regimens (C-III).

The start of antiretroviral therapy during tuberculosis treatment in naïve patients with advanced HIV infection may be safe and effective [58]. Tuberculosis treatment should preferably include rifampicin (A-II) and, due to drug-drug interactions, cART should be based on efavirenz together with two NRTI drugs (A-II). When a PI-containing regimen is adopted, rifampicin should be replaced by rifabutin (A-I). When rifabutin is prescribed in association with $\mathrm{PI} / \mathrm{r}$ or NNRTI, the dosage of the former drug should be modified (A-III). The regimens of tuberculosis therapy and timing of cART are summarized in table 3 based on the degree of immune-suppression at the diagnosis of tuberculosis.

\section{Immune Reconstitution Inflammatory Syndrome}

For all patients with tuberculosis, MAC, CMV retinitis, cryptococcal meningitis, and PML, the starting antiretroviral treatment should be accurately evaluated for the onset of IRIS [22, 23] (A-II). Studies have shown that the risk of IRIS is associated with baseline CD4 cell count as well as early initiation of cART and that severe, lifethreatening manifestations are uncommon $[48,59,60]$.

IRIS should be treated with anti-inflammatory drugs, such as nonsteroidal anti-inflammatory drugs (NSAIDs) or steroids, to control symptoms, and antiretroviral treatment should be continued. It may be necessary to stop antiretroviral treatment if the clinical picture of IRIS is severe (C-III).

\section{Prophylaxis Against Opportunistic Infections} In all patients with symptomatic advanced naïve HIV infection, primary prophylaxis against opportunistic infections other than those already diagnosed should be initiated as soon as possible (A-I). Drugs for primary prophylaxis can be prescribed at the same time as cART and other treatments for concomitant opportunistic infections (Table 2).

Secondary prophylaxis for opportunistic infections may be stopped once a stable immune recovery is reached by cART [61-66] (A-I). CD4+ T cell levels at which secondary prophylaxis can be withdrawn are shown in table 4.

\section{Principles of Antiretroviral Treatment and Monitoring in Naïve Patients with Advanced HIV Infection and Special Conditions or Co-morbidities Introduction}

This section examines the issues pertinent to naïve patients with advanced HIV infection and special conditions or comorbidities. Attention will focus on special populations, such as the elderly, who show a slower immune recovery, 


\begin{tabular}{|c|c|c|}
\hline $\begin{array}{l}\text { Opportunistic } \\
\text { infection }\end{array}$ & CD4+ T cell count & $\begin{array}{l}\text { Recommen- } \\
\text { dation }^{\text {a }}\end{array}$ \\
\hline$P$. jiroveci pneumonia & $>200$ cells $/ \mathrm{mm}^{3} \geq 3$ months & A-I \\
\hline $\begin{array}{l}\text { Cytomegalovirus } \\
\text { infection }\end{array}$ & $>100$ cells $/ \mathrm{mm}^{3} \geq 6$ months & A-II \\
\hline $\begin{array}{l}\text { Toxoplasmic } \\
\text { encephalitis }\end{array}$ & $>200$ cells $/ \mathrm{mm}^{3} \geq 6$ months & A-I \\
\hline Cryptococcosis & $>100$ cells $/ \mathrm{mm}^{3} \geq 6$ months & B-I \\
\hline MAC infection & $>100$ cells $/ \mathrm{mm}^{3} \geq 6$ months & B-II \\
\hline \multicolumn{3}{|c|}{$\begin{array}{l}\text { a The strength of the recommendations was graded: } A \text {, strong; B, } \\
\text { moderate; the quality of the evidence was classified: I, properly } \\
\text { randomized controlled trials with clinical and/or laboratory results; } \\
\text { II, other published studies with clinical and/or laboratory results }\end{array}$} \\
\hline
\end{tabular}

patients with neurocognitive disorders, who are frequently observed during severe immunosuppression [67, 68], and those co-infected with hepatitis viruses $[69,70]$.

\section{Older Age}

After starting cART, older patients show a reduced recovery of CD4+ $\mathrm{T}$ cells and an increased risk of progression to AIDS diagnosis, neurocognitive disorders, and death with respect to younger patients having comparable levels of CD4+ T cells and HIV viral loads [67, 68]. Therefore, in this patient population, the initiation of cART could be indicated at an earlier stage of disease. At the present time, cART must to be started at least when the CD4+ T cell level $<350 / \mathrm{mmc}$ (A-III) and may be considered in patients with CD4+ T cells between 350 and $500 / \mathrm{mm}^{3}$ and plasma HIV-1 RNA levels $>30,000 \mathrm{cp} / \mathrm{ml}$ (A-III). Specific studies on this topic are warranted.

\section{Neurocognitive Impairment}

In advanced naïve HIV patients or in patients with neurocognitive impairment not taking antiretroviral treatment, HIV-1 viral load level in the CSF correlates with the severity of HIV-related dementia and, therefore, may predict subsequent onset of neurocognitive impairments $[68,69]$. In all patients presenting with neurological signs and symptoms in whom a diagnostic lumbar puncture is indicated, the measurement of HIV-RNA in CSF should be added to all specific tests being performed to diagnose opportunistic infections (A-II).

All patients with advanced naïve HIV infection should undergo an accurate assessment of neuropsychological status using a validated cognitive test battery or a standardized scale for clinical measurements [71, 72]. This assessment should be repeated during follow-up in patients having a cognitive impairment and an abnormal baseline test result (A-II).

Patients with neurocognitive disorders and/or detectable HIV-1 RNA levels in the CSF before cART has been started should be prescribed antiretroviral regimens con- taining neuroactive drugs with a high penetration score in CSF $[68,73,74]$ (A-II). In the case of worsening clinical conditions and/or of neurocognitive tests, these patients should undergo lumbar puncture both to assess HIV-1 RNA levels in the CSF and to perform genotypic resistance test on the CSF virus in order to choose the most appropriate therapeutic option (B-III).

\section{Co-Infection with Hepatic Viruses}

Liver disease is one of the major causes of morbidity and mortality in HIV-infected patients [75, 76], and its severity has been associated with more advanced immunosuppression. HCV/HIV co-infection may accelerate HIV-related neurocognitive decline [69]. Further, HCV viremia seems to play a role in impairing the $\mathrm{CD} 4+\mathrm{T}$ cell count response to cART [70]. On the other hand, effective antiretroviral drugs use may contribute to worsening the liver disease [77]. Reversal or prevention of immunosuppression with cART will slow the progression of $\mathrm{HCV}$ disease.

The analyses to be performed in advanced naïve patients having abnormal liver function tests are summarized in table 5 .

In advanced naïve patients with chronic $\mathrm{HCV}$ infection, therapy with peg-IFN plus ribavirin is indicated:

- in all subjects achieving an adequate immune reconstitution and a stabilization of antiretroviral therapy, in the absence of contraindications, and following specific guidelines (A-II);

- when hepatopathy related to HCV co-infection represents a major obstacle to proper antiretroviral treatment (C-III).

All HBsAg-positive patients having HBV DNA levels $>2,000 \mathrm{IU} / \mathrm{ml}$ and/or cirrhosis should receive an antiretroviral regimen containing tenofovir (TDF) (possibly associated with 3TC/FTC) as part of the NRTI backbone (A-III). In patients in which TDF use is contraindicated or must be stopped, adefovir or entecavir should be used (B-II). It should be noted that entecavir is a potent partial inhibitor of HIV replication in vivo and in vitro and that it may select for viruses bearing the M184V mutation [78]. Therefore in HBV/HIV-coinfected patients, entecavir should not be used for the treatment of HBV infection without concomitant suppressive treatment for HIV (B-II). In subjects diagnosed with HBV-related cirrhosis, especially if the continuous performance test (CPT) score is $>5$, a pre-emptive treatment with entecavir or adefovir before starting cART may be considered in order to reduce the risk of decompensation during the phase of immune reconstitution (C-III). Before starting or modifying treatment against chronic HBV infection, it may be useful to have a HBV genotype test performed in order to identify mutational patterns that confer resistance to drugs against HBV (B-III).

Patients who are HBsAg- and/or HBcAb-positive and undergoing a period of severe immunodepression fol- 


\begin{tabular}{|c|c|c|}
\hline & Recommendation & Comments \\
\hline \multicolumn{3}{|l|}{ Markers of viral hepatitis } \\
\hline HBsAg, HBsAb, HBcAb, HCV IgG, HAV IgG & A-II & \\
\hline In HBsAg-positive patients: & & \\
\hline HBV-DNA, HBcAb IgM, HBeAg, HBeAb & A-II & \\
\hline IgM and IgG anti-HDV & A-II & \\
\hline HDV-RNA & B-II & \\
\hline \multicolumn{3}{|l|}{ In HCV IgG-positive patients: } \\
\hline Qualitative HCV-RNA & A-II & $\begin{array}{l}\text { In all patients with } \mathrm{CD} 4+\mathrm{T} \text { cells } \\
<200 / \mathrm{mm}^{3} \text { having negative test } \\
\text { results for HBsAg and HCV IgG }\end{array}$ \\
\hline HCV genotypic test & C-III & \\
\hline Exams for opportunistic infections possibly involving the liver & A-II & Depending on CD4+ T cells \\
\hline $\begin{array}{l}\text { Evaluation for non-infectious liver disorders: } \\
\text { Non-alcoholic steatohepatitis (NASH) } \\
\text { Alcoholic steatohepatitis (ASH) } \\
\text { Metabolic diseases } \\
\text { Other }\end{array}$ & B-II & \\
\hline Assessment of daily alcohol consumption & A-II & $\begin{array}{l}\text { Measured in mean number of daily } \\
\text { drinks }\end{array}$ \\
\hline Hepatic ultrasound & A-II & \\
\hline \multicolumn{3}{|l|}{ Identification of patients with liver cirrhosis } \\
\hline Abdominal ultrasonography & B-II & \\
\hline Indirect scores (FIB-4 and APRI scores) & B-II & \\
\hline Fibroscan technology & B-III & \\
\hline Liver biopsy & A-II & $\begin{array}{l}\text { If results of previous examinations } \\
\text { are not conclusive }\end{array}$ \\
\hline \multicolumn{3}{|l|}{ Further investigations in patients with live cirrhosis } \\
\hline Child-Turcotte Pugh (CTP) and model for end-stage liver disease (MELD) scores & A-II & \\
\hline Gastroscopy to identify possible esophageal varices at risk of bleeding & A-II & \\
\hline Six-monthly ultrasound screening for early detection of hepatocarcinoma & A-II & \\
\hline
\end{tabular}

lowing chemotherapy for neoplasms should receive prophylaxis against hepatitis $B$ reactivation (A-I) with cART containing TDF associated with or without 3TC/FTC, or alternatively entecavir (A-III).

No antiretroviral drug is contraindicated at the early stages of hepatopathy. In patients with advanced hepatopathy, antiretroviral regimens containing either TPV/ RTV (A-II), nevirapine (A-II), d-drugs (A-II), or abacavir (C-III) should be avoided [79].

\section{Acknowledgments}

The consensus conference was held under the patronage of the Italian Society for Infectious and Tropical Diseases (Società Italiana per le Malattie Infettive e Tropicali, SIMIT) and supported by an unrestricted grant from Abbott, Division Virology, Italy. The following participants are members of the Consensus Conference Working Group: L. Alba, A. Bandera, C. Blagetti, E. Boumis, A. Capetti, M. Carnevalini, A. Cingolani, N. Corso, M. D'Abbraccio, M. De Gennaro, S. Di Giambenedetto, F. Di Lorenzo, G. Dionisi, F. Di Sora, C. Fornabaio, A. Giacometti, S. Giancotti, S. Giglio, R. Gnarini, M. L. Giancola, M. D. Iannece,
J. Ivanovic, M. Lanzafame, G. Lapadula, L. Lonigro, A. Lupo, L. Maiocchi, M. Mannazzu, D. Manno, B. Mariani, L. Mecocci, M. Mena, N. Morandi, S. Nappa, G. Pantò, R. Pisapia, P. Pizzaferri, P. Rogasi, D. Sacchini, L. Scorzolini, L. Sighinolfi, M. Trezzi, M. P. Trotta, B. Vigo, U. Visco Comandini, M. Zaccarelli, L. Zaffiri. The authors thank O. Tagliaferri for helpful assistance in preparing the manuscript.

\section{References}

1. Schwarcz S, Hsu L, Dilley JW, Loeb L, Nelson K, Boyd S: Late diagnosis of HIV infection: trends, prevalence, and characteristics of persons whose HIV diagnosis occurred within 12 months of developing AIDS. J Acquir Immune Defic Syndr 2006; 43: 491-494.

2. Girardi E, Sabin CA, Monforte AD: Late diagnosis of HIV infection: epidemiological features, consequences and strategies to encourage earlier testing. J Acquir Immune Defic Syndr 2007; 46: $\mathrm{S}_{3}-\mathrm{S} 8$.

3. Battegay $M$, Fluckiger $\mathrm{U}$, Hirschel $\mathrm{B}$, Furrer $\mathrm{H}$ : Late presentation of HIV-infected individuals. Antivir Ther 2007; 12: 841-851.

4. Wood E, Hogg RS, Yip B, Harrigan PR, Montaner JS: Why are baseline HIV RNA levels 100,000 copies $/ \mathrm{mL}$ or greater associ- 
ated with mortality after the initiation of antiretroviral therapy? J Acquir Immune Defic Syndr 2005; 38: 289-295.

5. Sabin CA, Smith CJ, Youle M, Lampe FC, Bell DR, Puradiredja D, Lipman MC, Bhagani S, Phillips AN, Johnson MA: Deaths in the era of HAART: contribution of late presentation, treatment exposure, resistance and abnormal laboratory markers. AIDS 2006; 20: 67-71.

6. Dragsted UB, Mocroft A, Vella S, Viard JP, Hansen AB, Panos G, Mercey D, Machala L, Horban A, Lundgren JD, EuroSIDA study group: Predictors of immunological failure after initial response to highly active antiretroviral therapy in HIV-1-infected adults: a EuroSIDA study. J Infect Dis 2004; 190: 148-155.

7. Kaufmann GR, Furrer $H$, Ledergerber B, Perrin L, Opravil $M$, Vernazza P, Cavassini M, Bernasconi E, Rickenbach $M$, Hirschel B, Battegay M, Swiss HIV Cohort Study: Characteristics, determinants, and clinical relevance of CD4 T cell recovery to $<500$ cells/ microL in HIV type 1-infected individuals receiving potent antiretroviral therapy. Clin Infect Dis 2005; 41: 361-372.

8. Chene G, Sterne JA, May M, Costagliola D, Ledergerber B, Phillips AN, Dabis F, Lundgren J, D'Arminio Monforte A, de Wolf F, Hogg R, Reiss P, Justice A, Leport C, Staszewski S, Gill J, Fatkenheuer G, Egger ME, Antiretroviral Therapy Cohort Collaboration: Prognostic importance of initial response in HIV-1 infected patients starting potent antiretroviral therapy: analysis of prospective studies. Lancet 2003; 362: 679-686.

9. Palella FJ Jr, Deloria-Knoll M, Chmiel JS, Moorman AC, Wood KC, Greenberg AE, Holmberg SD, HIV Outpatient Study Investigators: Survival benefit of initiating antiretroviral therapy in HIV-infected persons in different $\mathrm{CD}_{4}+$ cell strata. Ann Intern Med 2003; 138: 620-626.

10. Panel on antiretroviral guidelines for adults and adolescents: Guidelines for the use of antiretroviral agents in HIV-1-infected adults and adolescents. Department of Health and Human Services. 29 January 2008; pp 1-128. Available at: http:// www.aidsinfo.nih.gov/ContentFiles/AdultandAdolescentGL.pdf. Accessed: 16 July 2008.

11. Centers for Disease Control and Prevention: Revised classification system for HIV infection and expanded surveillance case definition for AIDS among adolescents and adults. MMWR recommendations and reports. December 18, 1992/41 (RR-17).

12. Palella FJ Jr, Baker RK, Moorman AC, Chmiel JS, Wood KC, Brooks JT, Holmberg SD, HIV Outpatient Study Investigators: Mortality in the highly active antiretroviral therapy era: changing causes of death and disease in the HIV outpatient study. J Acquir Immune Defic Syndr 2006; 43: 27-34.

13. Phillips AN, Lundgren JD: The CD4 lymphocyte count and risk of clinical progression. Curr Opin HIV AIDS 2006; 1: 43-49.

14. Nunn P, Brindle R, Carpenter L, Odhiambo J, Wasunna K, Newnham R, Githui W, Gathua S, Omwega M, McAdam K: Cohort study of human immunodeficiency virus infection in patients with tuberculosis in Nairobi, Kenya. Analysis of early (6-month) mortality. Am Rev Respir Dis 1992; 146: 849-854.

15. Sax PE, Islam R, Walensky RP, Losina E, Weinstein MC, Goldie SJ, Sadownik SN, Freedberg KA: Should resistance testing be performed for treatment-naïve HIV-infected patients? A costeffectiveness analysis. Clin Infect Dis 2005; 41: 1316-1323.

16. Palmer S, Boltz V, Maldarelli F, Halvas E, Mellors J, Coffin J: New real-time PCR assay quantifies $\mathrm{K} 103 \mathrm{~N}$ NNRTI-resistant variant at a frequency as low as $0.01 \%$ [abstract $P_{3} 6$ ]. In: Program and abstracts of the National Cancer Institute third HIV drug resistance program symposium: antiviral drug resistance (Chantilly, VA, 8-11 December 2002). National Cancer Institute, Bethesda 2002, pp 74
17. Moyle GJ, Wildfire A, Mandalia S, Mayer H, Goodrich J, Whitcomb J, Gazzard BG: Epidemiology and predictive factors for chemokine receptor use in HIV-1 infection. J Infect Dis 2005; 191: 866-872.

18. Mallal S, Phillips E, Carosi G, Molina JM, Workman C, Tomazic J, Jägel-Guedes E, Rugina S, Kozyrev O, Cid JF, Hay P, Nolan D, Hughes $S$, Hughes A, Ryan S, Fitch N, Thorborn D, Benbow A, PREDICT-1 Study Team: HLA-B*5701 screening for hypersensitivity to abacavir. N Engl J Med 2008; 358: 568-579.

19. Benson CA, Kaplan JE, Masur H, Pau A, Holmes KK, CDC, National Institutes of Health; Infectious Diseases Society of America. Treating opportunistic infections among HIV-infected adults and adolescents: recommendations from CDC, the National Institutes of Health, and the HIV Medicine Association/ Infectious Diseases Society of America. MMWR Recomm Rep 17 Dec 2004; 53(RR-15): 1-112.

20. Brock I, Ruhwald M, Lundgren B, Westh $H$, Mathiesen LR, Ravn P: Latent tuberculosis in HIV positive, diagnosed by the $M$. tuberculosis specific interferon-gamma test. Respir Res 2006; 7: 56.

21. Gandhi RT, Spritzler J, Chan E, Asmuth DM, Rodriguez B, Merigan TC, Hirsch MS, Shafer RW, Robbins GK, Pollard RB, ACTG 384 Team: Effect of baseline- and treatment-related factors on immunologic recovery after initiation of antiretroviral therapy in HIV-1-positive subjects: results from ACTG 384. J Acquir Immune Defic Syndr 2006; 42: 426-434.

22. Robertson J, Meier M, Wall J, Ying J, Fichtenbaum CJ: Immune reconstitution syndrome in HIV: validating a case definition and identifying clinical predictors in persons initiating antiretroviral therapy. Clin Infect Dis 2006; 42: 1639-1646.

23. French MA, Price P, Stone SF: Immune restoration disease after antiretroviral therapy. AIDS 2004; 18: 1615-1627.

24. Ledergerber B, Egger $M$, Erard V, Weber R, Hirschel B, Furrer $H$, Battegay $M$, Vernazza P, Bernasconi E, Opravil M, Kaufmann D, Sudre P, Francioli P, Telenti A: AIDS-related opportunistic illnesses occurring after initiation of potent antiretroviral therapy: the Swiss HIV Cohort Study. JAMA 1999; 282: 2220-2226.

25. Smit C, Geskus R, Walker S, Sabin C, Coutinho R, Porter K, Prins M, CASCADE Collaboration: Effective therapy has altered the spectrum of cause-specific mortality following HIV seroconversion. AIDS 2006; 20: 741-749.

26. Jaen A, Esteve A, Montoliu A, Miro J, Podzamczer D, Tural C, Riera M, Segura F, Force L, Vilaro L, Garcia I, Masabeu A, Altes J, Sued O, Clotet B, Ferrer E, Casabona J, Piscis Study Group: When is the optimal moment to start HAART in HIV infected patients from PISCIS cohort study (Spain)? Program and abstracts of the 46th Interscience Conference on Antimicrobial Agents and Chemotherapy; 27-30 September 2006; San Francisco, California. Abstract $\mathrm{H}-1059$.

27. d'Arminio Monforte A, Sabin CA, Phillips A, Sterne J, May M, Justice A, Dabis F, Grabar S, Ledergerber B, Gill J, Reiss P, Egger $M$, The Antiretroviral Therapy Cohort Collaboration: The changing incidence of AIDS events in patients receiving highly active antiretroviral therapy. Arch Intern Med 2005; 165: 416-423.

28. Carosi G, Quiros-Roldan E, Torti C, Antinori A, Bevilacqua M, Bonadonna RC, Bonfanti P, Castagna A, Cauda R, d'Arminio-Monforte A, Di Gregorio P, Di Perri G, Esposito R, Fatuzzo F, Gervasoni C, Giannatasio C, Guaraldi G, Lazzarin A, Lo Caputo S, Maggi P, Mazzotta F, Moroni M, Prestileo T, Ranieri R, Rizzardini G, Russo R, Galli $M$, members of the Italian Cardiovascular Risk Guidelines Working Group: First Italian consensus statement on diagnosis, prevention and treatment of cardiovascular complications in HIVinfected patients in the ERA (2006). Infection 2007; 35: 1-9. 
29. Miller V, Phillips AN, Clotet B, Mocroft A, Ledergerber B, Kirk O, Ormaasen V, Gargalianos-Kakolyris P, Vella S, Lundgren JD: Association of virus load, CD4 cell count, and treatment with clinical progression in human immunodeficiency virus-infected patients with very low CD4 cell counts. J Infect Dis 2002; 186: 189-197.

30. Wood E, Hogg RS, Yip B, Harrigan PR, Montaner JS: Earlier initiation of highly active antiretroviral therapy does not protect against the deleterious effects of non-adherence. AIDS 2004; 18: 2432-2434

31. MacArthur RD, Novak RM, Peng G, Chen L, Xiang Y, Kozal MJ, van den Berg-Wolf $M$, Henely $C$, Huppler-Hullsiek $K$, Schmetter $B$, Dehlinger M, for the CPCRA 058 Study Team and the Terry Beirn Community Programs for Clinical Research on AIDS (CPCRA): Long-term clinical and immunologic outcomes are similar in HIV-infected persons randomized to NNRTI vs PI vs NNRTI + PI-based antiretroviral regimens as initial therapy: results of the CPCRA 058 FIRST study. Program and abstracts of the XVI International AIDS Conference; 13-18 August 2006, Toronto, Canada. Abstract TUABo102.

32. Pulido F, Arribas JR, Miro JM, Costa MA, Gonzalez J, Rubio R, Pena JM, Torralba M, Lonca M, Lorenzo A, Cepeda C, Vazquez JJ, Gatell JM, EfaVIP Cohort Study Group: Clinical, virologic, and immunologic response to efavirenz-or protease inhibitor-based highly active antiretroviral therapy in a cohort of antiretroviralnaïve patients with advanced HIV infection (EfaVIP 2 study). J Acquir Immune Defic Syndr 2004; 35: 343-350.

33. Riddler SA, Haubrich R, DiRienzo G, Peeples L, Powderly WG, Klingman KL, Garren KW, George T, Rooney JF, Brizz B, Havlir D, Mellors JW, AIDS Clinical Trials Group 5142 Study Team: A prospective, randomized, phase III trial of NRTI-, PI-, and NNRTI-sparing regimens for initial treatment of HIV-1 infection: ACTG 5142. Program and abstracts of the XVI International AIDS Conference; 13-18 August 2006, Toronto, Canada. Abstract THLBo204.

34. Barreiro P, Soriano V, Casas E, Gonzalez-Lahoz J: Different degree of immune recovery using antiretroviral regimens with protease inhibitors or non-nucleosides. AIDS 2002; 16: 245-249.

35. Olsen $\mathrm{CH}$, Gatell J, Ledergerber B, Katlama C, Friis-Moller N, Weber J, Horban A, Staszewski S, Lundgren JD, Phillips AN, EuroSIDA Study Group: Risk of AIDS and death at given HIV-RNA and $\mathrm{CD}_{4}$ cell count, in relation to specific antiretroviral drugs in the regimen. AIDS 2005; 19: 319-330.

36. Hicks C, King MS, Gulick RM, White AC Jr, Eron JJ Jr, Kessler HA, Benson C, King KR, Murphy RL, Brun SC: Long-term safety and durable antiretroviral activity of lopinavir/ritonavir in treatmentnaïve patients: 4 year follow-up study. AIDS 2004; 18: 775-779.

37. Murphy R, da Silva B, McMillan F, Hicks C, Eron J, Wolfe P, Gulick $R$, Glesby $M$, Thompson $M$, Benson C, White AC, Albrecht $M$, Kessler H, Niemi K, King K, Calhoun D, King M, Hanna G, Brun S: Seven year follow-up of a lopinavir/ritonavir-based regimen in antiretroviral-naïve subjects. In: 10th European AIDS Conference. 17-20 November 2005. Dublin. Abstract PE7.9/3.

38. Eron J, Yeni P, Gathe J Jr, Estrada V, DeJesus E, Staszewski S, Lackey P, Yau L, Sutherland-Phillips D, Wannamaker P, Shaefer M: The KLEAN study: fosamprenavir + ritonavir (FPV/r) versus lopinavir/ritonavir (LPV/r) in antiretroviral-naïve (ART naïve) HIV-1 infected adults over 48 weeks. Program and abstracts of the XVI International AIDS Conference, 13-18 August 2006, Toronto, Canada. Abstract THLBo205.

39. Smith K, Weinberg W, DeJesus E, et al. Efficacy and safety of once-daily boosted fosamprenavir (FPV/r) or atazanavir (ATV/r) with tenofovir (TDF)/emtricitabine (FTC) in antiretroviral-naïve HIV-infected patients: 24-week results from COL103952 (ALERT).
Program and abstracts of the 46th interscience conference on antimicrobial agents and chemotherapy, 27-30 September 2006, San Francisco, CA. Abstract H-1670a.

40. Clumeck N, Van Lunzen J, Chiliade P, Clotet B, Vanden Abeele C, Lefebvre E, Vangeneugden T, Spinosa-Guzman S, DeMasi R: ARTEMIS - Efficacy and Safety of Lopinavir (BID vs OD) and Darunavir (OD) in Antiretroviral-naïve Patients. In: 11th European AIDS Conference, Madrid, 2007. Abstract LBPS7/5.

41. Gulick RM, Ribaudo HJ, Shikuma CM, Lalama C, Schackman BR, Meyer WA 3rd, Acosta EP, Schouten J, Squires KE, Pilcher CD, Murphy RL, Koletar SL, Carlson M, Reichman RC, Bastow B, Klingman KL, Kuritzkes DR, AIDS Clinical Trials Group (ACTG) A5095 Study Team: Three- vs four-drug antiretroviral regimens for the initial treatment of HIV-1 infection: a randomized controlled trial. JAMA 2006; 296: 769-781.

42. Delfraissy JF, Flandre $P$, Delaugerre $C$, Horban A, Girard PM, Rouzioux C, Norton M, Cohen-Codar I, NgoVan P, Chauvin JP: 48 Week analysis of LPV/r monotherpay compared to LPV/r + AZT/3TC in antiretroviral- naïve patients: MONARK trial. XVI International AIDS Conference, 13-18 Aug 2006, Toronto, Canada. Abstract THLBO2O2.

43. Boyd MA, Dixit NM, Siangphoe U, Buss NE, Salgo MP, Lange JM, Phanuphak P, Cooper DA, Perelson AS, Ruxrungtham K: Viral decay dynamics in HIV-infected patients receiving ritonavirboosted saquinavir and efavirenz with or without enfuvirtide: a randomized, controlled trial (HIV-NAT 012). J Infect Dis 2006; 194: 1319-1322.

44. Antinori A, Cozzi-Lepri A, Ammassari A, Trotta MP, Nauwelaers D, Hoetelmans R, Murri R, Melzi S, Narciso P, Nasta P, Zaccarelli $M$, Santopadre P, Vecchiet J, Izzo CM, Monforte A, AdICoNA Study Group: Relative prognostic value of self-reported adherence and plasma NNRTI/PI concentrations to predict virological rebound in patients initially responding to HAART. Antivir Ther 2004; 9: 291-296.

45. Bangsberg DR, Acosta EP, Gupta R, Guzman D, Riley ED, Harrigan PR, Parkin N, Deeks SG: Adherence-resistance relationships for protease and non-nucleoside reverse transcriptase inhibitors explained by virological fitness. AIDS 2006; 20: 223-231.

46. Wood E, Hogg RS, Yip B, Moore D, Harrigan PR, Montaner JS: Impact of baseline viral load and adherence on survival of HIVinfected adults with baseline CD4 cell counts $>$ or $=200$ cells $/$ microl. AIDS 2006; 20: 111711-111723.

47. Glass TR, De Geest $S$, Hirschel B, Battegay M, Furrer H, Covassini $M$, Vernazza PL, Bernasconi E, Rickenboch $M$, Weber R, Bucher HC, Swiss HIV Cohort Study: Self-reported non-adherence to antiretroviral therapy repeatedly assessed by two questions predicts treatment failure in virologically suppressed patients. Antivir Ther 2008; 13: 77-85.

48. Zolopa A, Andersen J, Komarow L, Sanchez A, Suckow C, Sanne I, Hogg E, Powderly W, and ACTG A5164 Study Team: Immediate vs deferred ART in the setting of acute AIDS-related opportunistic infection: final results of a randomized strategy trial, ACTG A5164. In: 15th Conference on Retroviruses and Opportunistic Infections. Boston (MA) 3-6 February 2008 (Abstract 142).

49. Kempen JH, Jabs DA, Wilson LA, Dunn JP, West SK, Tonascia J: Mortality risk for patients with cytomegalovirus retinitis and acquired immune deficiency syndrome. Clin Infect Dis 2003; 37: 1365-1373.

50. Antinori A, Larussa D, Cingolani A, Lorenzini P, Bossolasco $S$, Finazzi MG, Bongiovanni $M$, Guaraldi G, Grisetti S, Vigo B, Gigli B, Mariano A, Dalle Nogare ER, De Marco M, Moretti F, Corsi P, Abrescia N, Rellecati P, Castagna A, Mussini C, Ammassari A, Cinque $\mathrm{P}$, d'Arminio Monforte A, Italian Registry Investigative 
NeuroAIDS: Prevalence, associated factors, and prognostic determinants of AIDS-related toxoplasmic encephalitis in the era of advanced highly active antiretroviral therapy. Clin Infect Dis 2004; 39: 1681-1691.

51. Morris A, Wachter RM, Luce J, Turner J, Huang L: Improved survival with highly active antiretroviral therapy in HIV-infected patients with severe Pneumocystis carinii pneumonia. AIDS 2003; 17: 73-80.

52. Wislez M, Bergot E, Antoine M, Parrot A, Carette MF, Mayaud C, Cadranel J: Acute respiratory failure following HAART introduction in patients treated for Pneumocystis carinii pneumonia. Am J Respir Crit Care Med 2001; 164: 847-851.

53. Spano JP, Costagliola D, Katlama C, Mounier N, Oksenhendler E, Khayat D: AIDS-Related Malignancies: State of the Art and Therapeutic Challenges. J Clin Oncol 2008; 26: 4834-4842.

54. Antinori A, Cingolani A, Alba L, Ammassari A, Serraino D, Ciancio BC, Palmieri F, De Luca A, Larocca LM, Ruco L, Ippolito G, Cauda $R$ : Better response to chemotherapy and prolonged survival in AIDS-related lymphomas responding to highly active antiretroviral therapy. AIDS 2001; 15: 1483-1491.

55. Hoffmann C, Wolf E, Fatkenheuer G, Buhk T, Stoehr A, Plettenberg A, Stellbrink HJ, Jaeger $H$, Siebert U, Horst HA: Response to highly active antiretroviral therapy strongly predicts outcome in patients with AIDS-related lymphoma. AIDS 2003; 17: 1521-1529.

56. Simcock $M$, Blasko $M$, Karrer U, Bertisch B, Pless $M$, Blumer L, Vora S, Robinson JO, Bernasconi E, Terziroli B, Moirandat-Rytz $S$, Furrer H, Hirschel B, Vernazza P, Sendi P, Rickenbach M, Bucher HC, Battegay M, Koller MT, Swiss HIV Cohort Study: Treatment and prognosis of AIDS-related lymphoma in the era of highly active antiretroviral therapy: findings from the Swiss HIV Cohort Study. Antivir Ther 2007; 12: 931-939.

57. Cheung MC, Pantanowitz L, Dezube BJ: AIDS-related malignancies: emerging challenges in the era of highly active antiretroviral therapy. Oncologist 2005; 10: 412-426.

58. Sungkanuparph S, Manosuthi W, Kiertiburanakul S, Vibhagoo A: Initiation of antiretroviral therapy in advanced AIDS with active tuberculosis: clinical experiences from Thailand. J Infect 2006; 52: 188-194.

59. Lawn SD, Myer L, Bekker LG, Wood R: Tuberculosis-associated immune reconstitution disease: incidence, risk factors and impact in an antiretroviral treatment service in South Africa. AIDS 2007; 21: 335-341.

6o. Murdoch DM, Venter WD, Feldman C, Van Rie A: Incidence and risk factors for the immune reconstitution inflammatory syndrome in HIV patients in South Africa: a prospective study. AIDS 2008; 22: 601-610.

61. Mussini C, Pezzotti P, Antinori A, Borghi V, Monforte A, Govoni A, De Luca A, Ammassari A, Mongiardo N, Cerri MC, Bedini A, Beltrami C, Ursitti MA, Bini T, Cossarizza A, Esposito R, Changes in Opportunistic Prophylaxis (CIOP) Study Group: Discontinuation of secondary prophylaxis for Pneumocystis carinii pneumonia in human immunodeficiency virus-infected patients: a randomized trial by the CIOP Study Group. Clin Infect Dis 2003; 36: 645-651.

62. Zellweger C, Opravil M, Bernasconi E, Cavassini M, Bucher HC, Schiffer V, Wagels T, Flepp M, Rickenbach M, Furrer H, Swiss HIV Cohort Study: Long-term safety of discontinuation of secondary prophylaxis against Pneumocystis pneumonia: prospective multicentre study. AIDS 2004; 18: 2047-2053.

63. Kirk O, Reiss P, Uberti-Foppa C, Bickel M, Gerstoft J, Pradier C, Wit FW, Ledergerber B, Lundgren JD, Furrer H, European HIV Cohorts: Safe interruption of maintenance therapy against previous infection with four common HIV-associated opportu- nistic pathogens during potent antiretroviral therapy. Ann Intern Med 2002; 137: 239-250.

64. Miro JM, Lopez JC, Podzamczer D, Pena JM, Alberdi JC, Martinez E, Domingo P, Cosin J, Claramonte X, Arribas JR, Santin M, Ribera E, GESIDA 04/98 Study Group: Discontinuation of primary and secondary Toxoplasma gondii prophylaxis is safe in HIV-infected patients after immunological restoration with highly active antiretroviral therapy: results of an open, randomized, multicenter clinical trial. Clin Infect Dis 2006; 43: 79-89.

65. Berenguer J, Gonzalez J, Pulido F, Padilla B, Casado JL, Rubio R, Arribas JR, Madrid Group for the Study of Discontinuation of Secondary Prophylaxis in Patients with CMV Retinitis: Discontinuation of secondary prophylaxis in patients with cytomegalovirus retinitis who have responded to highly active antiretroviral therapy. Clin Infect Dis 2002; 34: 394-397.

66. Vibhagool A, Sungkanuparph S, Mootsikapun $P$, Chetchotisakd $P$, Tansuphaswaswadikul S, Bowonwatanuwong C, Ingsathit A: Discontinuation of secondary prophylaxis for cryptococcal meningitis in human immunodeficiency virus-infected patients treated with highly active antiretroviral therapy: a prospective, multicenter, randomized study. Clin Infect Dis 2003; 36: 1329-1331.

67. McArthur JC, McDermott MP, McClernon D, St Hillaire C, Conant K, Marder K, Schifitto G, Selnes OA, Sacktor N, Stern Y, Albert SM, Kieburtz K, de Marcaida JA, Cohen B, Epstein LG: Attenuated central nervous system infection in advanced HIV/AIDS with combination antiretroviral therapy. Arch Neurol 2004; 61: 1687-1696.

68. Tozzi V, Balestra P, Galgani S, Narciso P, Sampaolesi A, Antinori A, Giulianelli $M$, Serraino D, Ippolito G: Changes in neurocognitive performance in a cohort of patients treated with HAART for 3 years. J Acquir Immune Defic Syndr 2001; 28: 19-27.

69. Parsons TD, Tucker KA, Hall CD, Robertson WT, Eron JJ, Fried MW, Robertson KR: Neurocognitive functioning and HAART in HIV and hepatitis C virus co-infection. AIDS 2006; 20: 1591-1595.

70. Antonucci G, Girardi E, Cozzi-Lepri A, Capobianchi MR, De Luca A, Puoti M, Petrelli E, Carnevale G, Rizzardini G, Grossi PA, Vigano P, Moioli MC, Carletti F, Solmone M, Ippolito G, Monforte AD, Hepal.Co.N.A. Study Group, Italian Cohort naïve for Antiretrovirals Study Group: Role of hepatitis C virus (HCV) viremia and HCV genotype in the immune recovery from highly active antiretroviral therapy in a cohort of antiretroviral-naïve HIVinfected individuals. Clin Infect Dis 2005; 40: e101-e109.

71. Schifitto G, Kieburtz K, McDermott MP, McArthur J, Marder K, Sacktor N, Palumbo D, Selnes O, Stern Y, Epstein L, Albert S: Clinical trials in HIV-associated cognitive impairment: cognitive and functional outcomes. Neurology 2001; 56: 415-418.

72. Marra CM, Lockhart D, Zunt JR, Perrin M, Coombs RW, Collier AC: Changes in CSF and plasma HIV-1 RNA and cognition after starting potent antiretroviral therapy. Neurology 2003; 60: 1388-1390.

73. Capparelli EV, Holland D, Okamoto C, Gragg B, Durelle J, Marquie-Beck J, van den Brande G, Ellis R, Letendre S, HNRC Group: Lopinavir concentrations in cerebrospinal fluid exceed the 50\% inhibitory concentration for HIV. AIDS 2005; 19: 949-952.

74. Antinori A, Perno CF, Giancola ML, Forbici F, Ippolito G, Hoetelmans RM, Piscitelli SC: Efficacy of cerebrospinal fluid (CSF)penetrating antiretroviral drugs against HIV in the neurological compartment: different patterns of phenotypic resistance in CSF and plasma. Clin Infect Dis 2005; 41: 1787-1793.

75. Pineda JA, Romero-Gomez M, Diaz-Garcia F, Giron-Gonzalez JA, Montero JL, Torre-Cisneros J, Andrade RJ, Gonzalez-Serrano M, Aguilar J, Aguilar-Guisado M, Navarro JM, Salmeron J, Caballero- 
Granado FJ, Garcia-Garcia JA; Grupo Andaluz para el Estudio de las Enfermedades Infecciosas; Grupo Andaluz para el Estudio del Higado: HIV coinfection shortens the survival of patients with hepatitis $C$ virus-related decompensated cirrhosis. Hepatology 2005; 41: 779-789.

76. Konopnicki D, Mocroft A, de Wit S, Antunes F, Ledergerber B, Katlama C, Zilmer K, Vella S, Kirk O, Lundgren JD, EuroSIDA Group: Hepatitis B and HIV: prevalence, AIDS progression, response to highly active antiretroviral therapy and increased mortality in the EuroSIDA cohort. AIDS 2005; 19: 593-601.

77. Sulkowski MS, Mehta SH, Torbenson M, Afdhal NH, Mirel L, Moore RD, Thomas DL: Hepatic steatosis and antiretroviral drug use among adults coinfected with HIV and hepatitis $C$ virus. AIDS 2005; 19: 585-592.

78. Sasadeusz J, Audsley J, Mijch A, Baden R, Caro J, Hunter H, Matthews G, McMahon MA, Olender SA, Siliciano RF, Lewin SR, Thio CL: The anti-HIV activity of entecavir: a multicentre evaluation of lamivudine-experienced and lamivudine-naïve patients. AIDS. 2008; 22: 947-955.

79. Sulkowski MS, Mehta SH, Chaisson RE, Thomas DL, Moore RD: Hepatotoxicity associated with protease inhibitor-based antiretroviral regimens with or without concurrent ritonavir. AIDS 2004; 18: 2277-2284. 